Article

\title{
The Effects of Bone Morphogenetic Protein-4 on Cellular Viability, Osteogenic Potential, and Global Gene Expression on Gingiva-Derived Stem Cell Spheroids
}

\author{
Jae-Yong Tae ${ }^{1,2}$, Yoon-Hee Park ${ }^{3}$, Youngkyung Ko ${ }^{1,2}$ and Jun-Beom Park 1,2,*D \\ 1 Department of Medicine, Graduate School, The Catholic University of Korea, Seoul 06591, Korea; \\ taejaeyong@naver.com (J.-Y.T.); ko_y@catholic.ac.kr (Y.K.) \\ 2 Department of Periodontics, College of Medicine, The Catholic University of Korea, Seoul 06591, Korea \\ 3 ebiogen, Seonyu-ro 13-gil, Yeongdeungpo-gu, Seoul 07282, Korea; yhpark@e-biogen.com \\ * Correspondence: jbassoon@catholic.ac.kr; Tel.: +82-10-4325-2651
}

Received: 15 September 2020; Accepted: 22 October 2020; Published: 30 October 2020

\begin{abstract}
Bone morphogenetic protein-4 (BMP-4) is engaged in the migration ability of mesenchymal stem cells and the transition of mesenchymal stem cells into osteogenic and adipocytic lines. The aim of this study was to evaluate the effects of BMP-4 on the cellular viability, osteogenic differentiation, and genome-wide mRNA levels using three-dimensional cell spheroids composed of stem cells. Stem cell spheroids were formed using concave microwells in the presence of BMP-4 with final concentrations of $0,2,6$, and $10 \mathrm{ng} / \mathrm{mL}$. Cellular viability was measured qualitatively using a microscope and quantitatively using an assay kit based on water-soluble tetrazolium salt. Osteogenic differentiation was assessed by measuring the level of alkaline phosphatase activity. Global gene expression was assessed using next-generation mRNA sequencing and performing gene ontology and pathway analyses. Spheroids were well-maintained with the addition of BMP-4 up to Day 7. No significant differences were observed in cell viability between each group. There were significantly higher alkaline phosphatase values in the $2 \mathrm{ng} / \mathrm{mL}$ BMP-4 groups when compared with the control $(p<0.05)$. A total of 25,737 mRNAs were differentially expressed. Expression of $\beta$-catenin (CTNNB1) was increased with higher dosages of BMP-4. The expression of runt-related transcription factor 2 (RUNX2) was increased up to $6 \mathrm{ng} / \mathrm{mL}$. The phosphoinositide-3-kinase-protein kinase B/Akt signaling pathway was associated with the target genes. This study demonstrates that the application of BMP-4 enhanced alkaline phosphatase activity and the expression of CTNNB1 and RUNX2 without affecting cellular viability.
\end{abstract}

Keywords: bone morphogenetic protein 4; cell differentiation; cellular spheroids; gingiva osteogenesis; stem cells

\section{Introduction}

Mesenchymal stem cells (MSCs) are multipotent cells that can differentiate into the mesenchymal lineage and easily cultured in vitro [1]. A previous study demonstrated that stem cell spheroids of various sizes could be generated from gingival cells using microwells and that the shape and viability of the spheroids could be maintained [2]. Furthermore, cell spheroids made from gingival cells and osteoblast cells were able to maintain shape, viability, and osteogenic differentiation ability [3]. Stem cell therapy has been of great interest in recent years [4]. A two-dimensional culture has long been applied for the evaluation of viability and functionality of stem cells [3]. In more recent years, three-dimensional cultures have been used by applying various methods including the hanging drop 
method, bioreactor, capsules, and microwells [5]. Three-dimensional cultures have been reported to mimic the in vivo situation more closely [6]. A three-dimensional culture can be categorized by scaffold-based or scaffold-free application [7]. Three-dimensional spheroids can be made of a variety of cells including stem cells with the scaffold-free technique [8]. Spheroids can be used to obtain an overall enhancement in therapeutic potential by improving survival, stemness, angiogenic properties, and anti-inflammatory effects [9].

Bone morphogenetic proteins (BMPs) are powerful growth factors in the transforming growth factor beta superfamily [10]. More than twenty members with various functions have already been identified in humans, with roles in processes such as skeletal formation, hematopoiesis, and neurogenesis [11]. These BMPs are soluble local-acting signaling proteins that may behave in an endocrine, paracrine, or autocrine manner [12]. BMP-4 may be involved in various functions, including enhancing the migration ability of mesenchymal stem cells and the transition from mesenchymal stem cells into the osteogenic and adipocytic lines [13,14]. BMP-4 may act as an important regulator for proper reproductive tissue development [15]. Moreover, BMP-4 is reported to be involved in postnatal tooth cytodifferentiation [16]. BMP-4 has been suggested as a coating material for titanium implants [17]. To the best of the authors' knowledge, there are no previous studies evaluating the effects of BMP-4 on the cell spheroids composed of gingiva-derived stem cells using microwells. In light of the promising findings in previous studies on BMP-4, the aim of the present study was to evaluate the effects of BMP-4 on cellular viability, osteogenic differentiation, and genome-wide mRNA levels using stem cell spheroids.

\section{Materials and Methods}

\subsection{Formation of Cell Spheroids with Gingiva-Derived Stem Cells}

Cell spheroids were made of gingiva-derived mesenchymal stem cells using the concave microwells made of silicone elastomer having $600 \mu \mathrm{m}$ diameters (H389600, StemFIT 3D; MicroFIT, Seongnam, Korea). The number of cells loaded in each well was $1 \times 10^{6}$. We obtained approval from the Institutional Review Board at Seoul St Mary's Hospital, Seoul, Korea (KC20SISE0695), and informed consent was obtained from the participant. Cell spheroids made were treated with BMP-4 (ProSpec, Ness-Ziona, Israel) at $0,2,6$, and $10 \mathrm{ng} / \mathrm{mL}$ concentrations. The morphological changes in cell spheroids were observed under an inverted microscope (Leica DM IRM, Leica Microsystems, Wetzlar, Germany). The changes in the spheroids' diameter were evaluated on Days 1,3,5, and 7 . The diameter of the spheroids was determined as described in a previous study [18]. Figure 1 diagrams the overall design of the study.

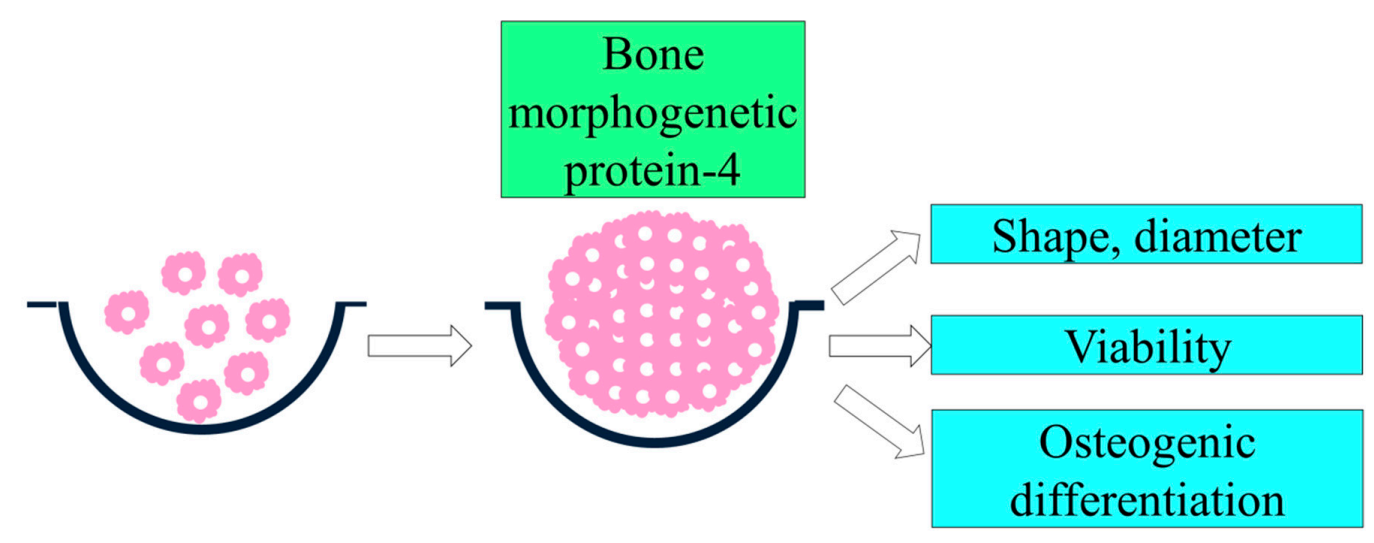

Figure 1. Schematic overview of the present study's design. 


\subsection{Evaluation of Cellular Viability}

Qualitative analysis of the cell spheroids for cellular viability was done using the Live/Dead assay kit (Molecular Probes, Eugene, OR, USA). These spheroids were washed twice with the growth media before calcein acetoxymethyl (Molecular Probes) and ethidium homodimer-1 (Molecular Probes) were added for an incubation period of $30 \mathrm{~min}$ at room temperature. Then, the spheroids were evaluated using a fluorescence microscope (Axiovert 200; Zeiss, Oberkochen, Germany) on Days 3 and 7.

Quantitative analysis of cell viability was performed using the cell counting kit-8 (CCK-8; Dojindo, Tokyo, Japan) on Days 1, 3, 5, and 7. WST-8 solution was added to the stem cell spheroids, which were then cultured for $45 \mathrm{~min}$ at $37^{\circ} \mathrm{C}$. Absorbance was measured using a microplate reader at $450 \mathrm{~nm}$ (BioTek, Winooski, VT, USA).

\subsection{Evaluation of Osteogenic Differentiation Using Alkaline Phosphatase Activity Assays}

Cell spheroids were grown in osteogenic medium and were collected on Days 1, 3, 5, and 7. A commercially available alkaline phosphatase assay kit (K412-500, BioVision, Inc., Milpitas, CA, USA) was used for the evaluation of osteogenic differentiation. In short, the resultant supernatant was mixed and incubated with p-nitrophenyl phosphate substrate (BioVision, Inc.) for $40 \mathrm{~min}$ at room temperature. Absorbance was measured using a microplate reader at $405 \mathrm{~nm}$ (BioTek, Winooski, VT, USA).

\subsection{Sequencing of mRNA, Gene Ontology, and Pathway Analysis}

Construction of a library of RNAs was performed using the SENSE mRNA-Seq Library Prep Kit (Lexogen, Inc., Vienna, Austria). Briefly, $2 \mu \mathrm{g}$ of total RNA was processed and incubated with oligo-dT magnetic beads, after which other RNAs except mRNA were eliminated with a washing solution. Random hybridization of starter/stopper heterodimers was applied to the poly(A)RNA still bound to the magnetic beads in order to produce libraries. These heterodimers consisted of Illumina-compatible linker sequences. A single-tube reverse transcription and ligation reaction was applied to extend the starter to the next hybridized heterodimer. Then, the newly synthesized cDNA insert was bound with the stopper. The release of the library from the beads was done by second-strand synthesis. The library was amplified afterward and bar codes were introduced. High-throughput sequencing was done using HiSeq 2500 (Illumina, San Diego, CA, USA) as paired-end $100 \mathrm{bp}$ sequencing.

Software tools (TopHat, Toronto, ON, Canada) were used to map RNA-Seq reads. Transcript assembly and detection of differentially expressed genes or isoforms were performed from the alignment file using cufflinks [19]. The quantile normalization method was used for comparison between samples [20]. Functional gene classification was done using Medline databases (http://www.ncbi.nlm.nih.gov/), DAVID (http://david.abcc.ncifcrf.gov/), GenMAPP (http: //www.genmapp.org/), and BioCarta (http://www.biocarta.com/) [21]. Pathway analysis was performed on differentially expressed genes [22]. A fold-change of 1.3 and a log2-normalized read count of 4 were the thresholds applied for this study [23].

\subsection{Statistical Analysis}

All statistical analysis was performed using SPSS 12 for Windows (SPSS Inc., Chicago, IL, USA). A one-way analysis of variance with Tukey's post-hoc test was used to evaluate the differences between each group after performing a test of normality. A $p$-value less than 0.05 was set as the threshold for statistical significance.

\section{Results}

\subsection{Formation of Cell Spheroids with Human Gingiva-Derived Stem Cells}

Spheroids were well-established in each microwell on Day 1 (Figure 2). Furthermore, no noticeable changes in the shape of the cell spheroids were observed with the addition of BMP-4 at concentrations 
of 2,6, or $10 \mathrm{ng} / \mathrm{mL}$. There were no noticeable changes at the longer culturing times. The spheroid diameters are shown in Figure 3. There was a general decrease in the diameter of the spheroids with longer incubation time.

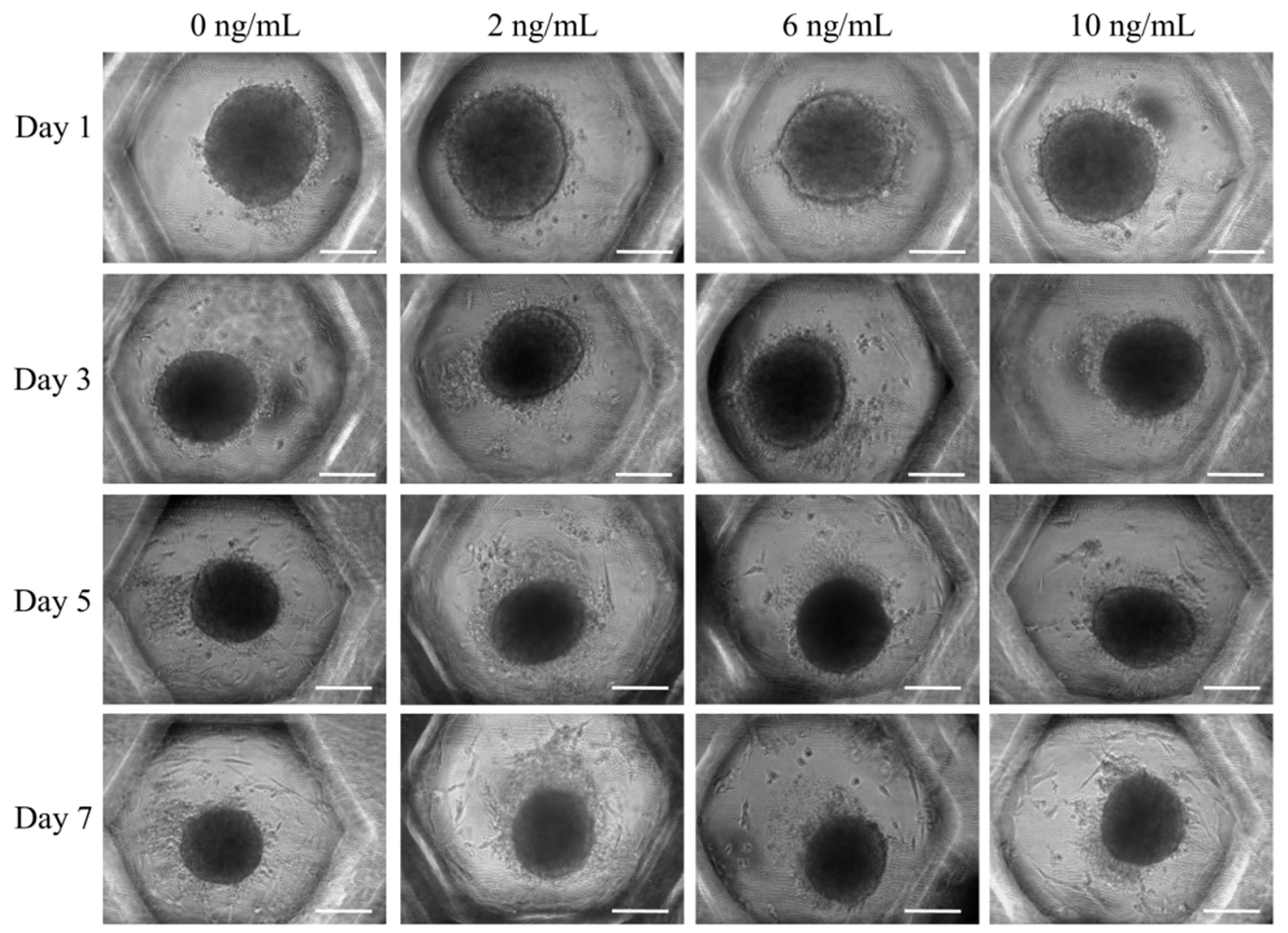

Figure 2. Spheroid morphology on Days 1, 3, 5, and 7. The scale bar indicates $200 \mu \mathrm{m}$.

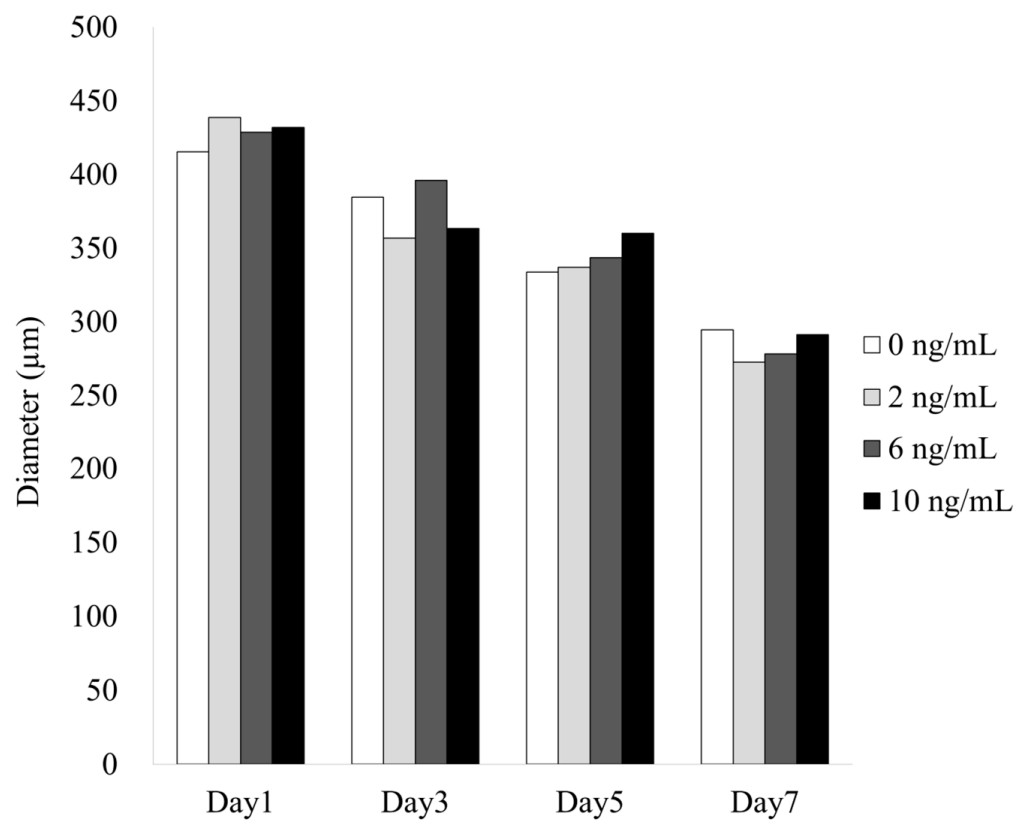

Figure 3. Diameter of the spheroids on Days 1,3,5, and 7. The spheroids were treated with BMP-4 at concentrations of $0,2,6$, or $10 \mathrm{ng} / \mathrm{mL}$. 


\subsection{Determination of Cellular Viability}

Figure $4 \mathrm{~A}$ shows qualitative results for the viability of cell spheroids at Day 3 using a Live/Dead assay kit (Figure 4A). In all cases, the cells in the spheroids produced intense green fluorescence. Red fluorescence was partly noted around the boundary of the spheroids. No significant differences were noted at Day 7 when compared with results of Day 3 (Figure 4B). Figure 4C shows the quantitative results for cellular viability on Days 1,3,5, and 7. No significant differences were observed among the groups on Day $1(p>0.05)$. In general, there were no significant differences among the groups with longer incubation times.

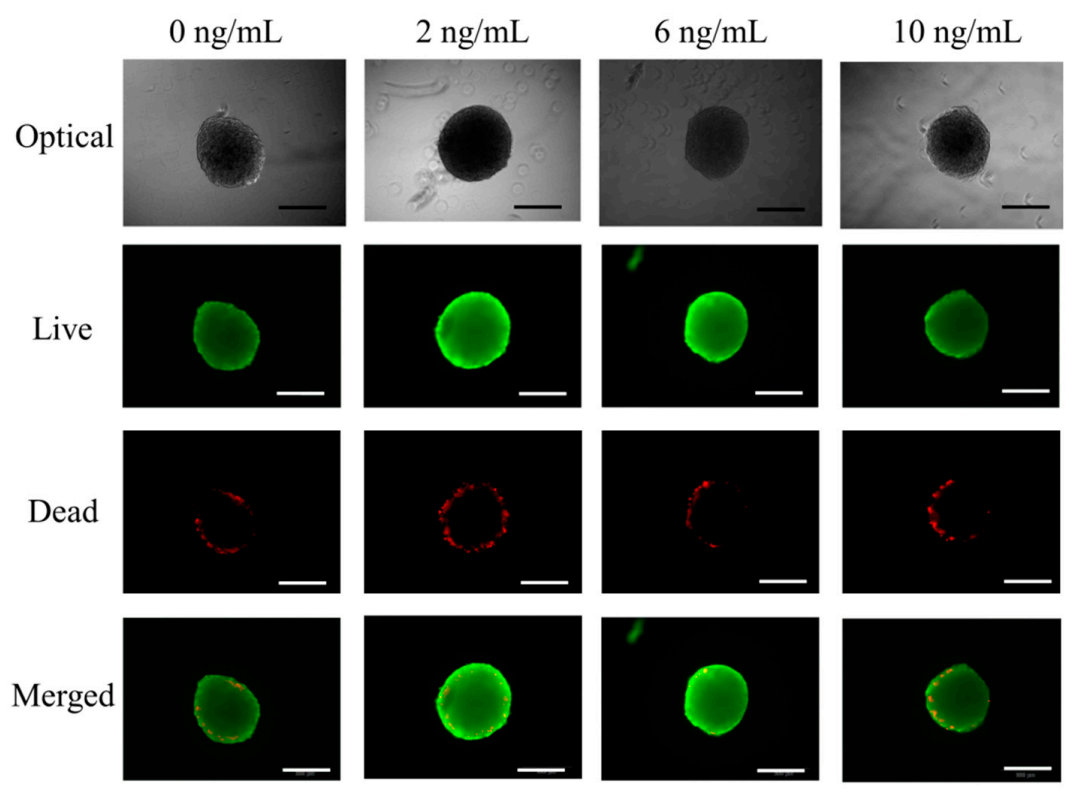

(A)

Figure 4. Cont. 


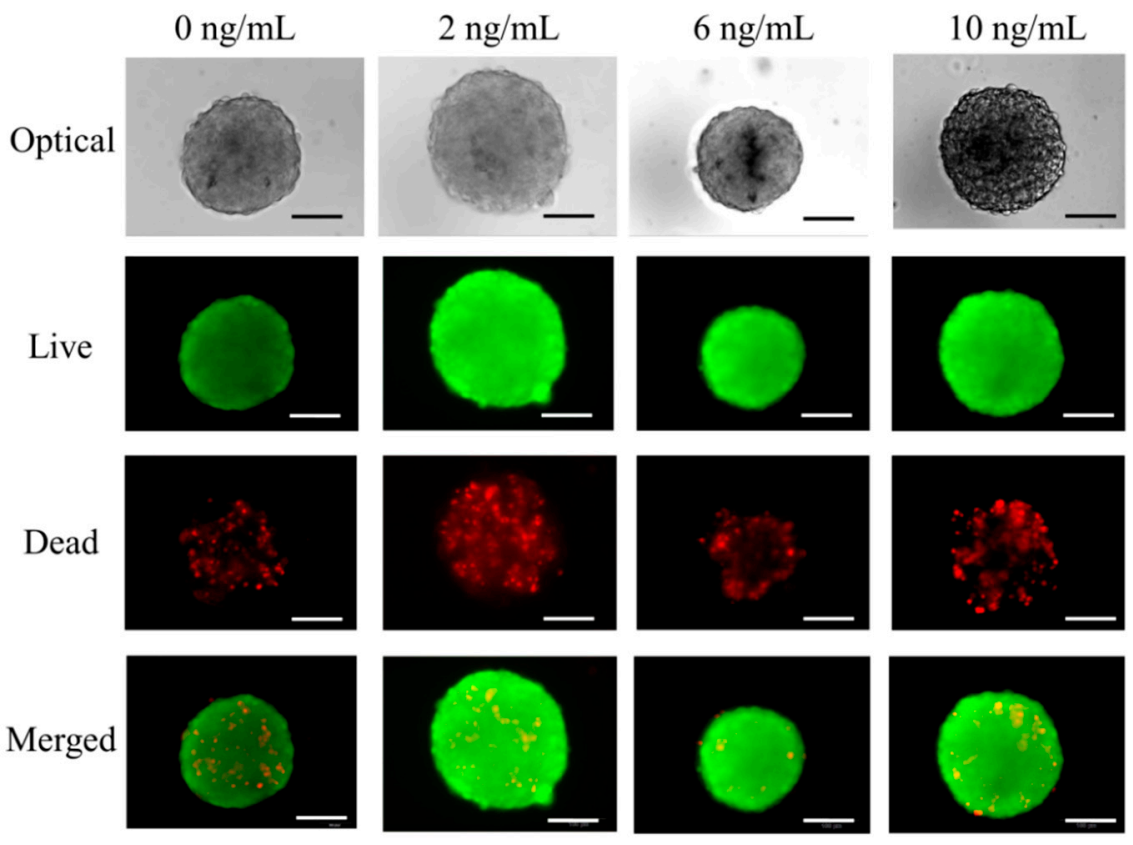

(B)

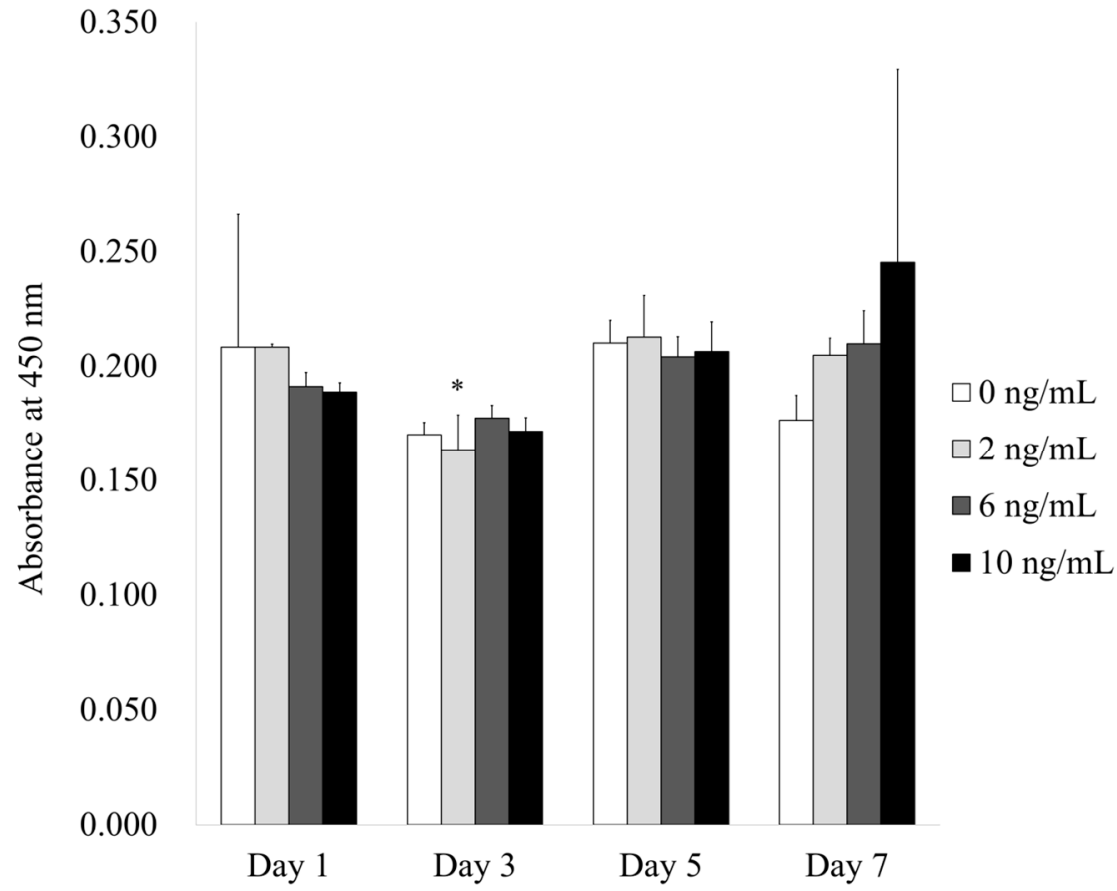

(C)

Figure 4. (A) Optical, live, dead, and merged images of stem cell spheroids on Day 3. The scale bar indicates $200 \mu \mathrm{m}$. (B) Results of optical, live, dead, and merged images of stem cell spheroids on Day 7. The scale bar represents $200 \mu \mathrm{m}$. (C) Cellular viability using CCK-8 assay on Days 1, 3, 5, and 7. * Statistically significant differences were noted when compared with the $2 \mathrm{ng} / \mathrm{mL}$ group on Day 1 $(p<0.05)$.

\subsection{Evaluation of Alkaline Phosphatase Activity Assay with the Addition of BMP-4}

The results of the alkaline phosphatase activity assay at Days 1, 3, 5, and 7 are presented in Figure 5. In general, there were increases in the alkaline phosphatase activity with longer incubation 
time up to Day 7. Notably, the group treated with $2 \mathrm{ng} / \mathrm{mL}$ BMP-4 at Day 3 had a significantly higher activity compared with that of the control group at Day $3(p<0.05)$.

\subsection{Gene Ontology}

A total of 25,737 mRNAs were differentially expressed. Scatter plots of the differentially expressed mRNAs are shown in Figure 6. A Venn diagram of the gene ontology analysis of differentially expressed mRNAs is shown in Figure 7. When compared with the $0 \mathrm{ng} / \mathrm{mL}$ control group, $1270 \mathrm{mRNAs}$ were upregulated and $1070 \mathrm{mRNAs}$ were downregulated in the $2 \mathrm{ng} / \mathrm{mL}$ group. In the $6 \mathrm{ng} / \mathrm{mL}$ group, 1536 mRNAs were upregulated and 1889 mRNAs were downregulated compared to controls. In the $10 \mathrm{ng} / \mathrm{mL}$ group, $1525 \mathrm{mRNAs}$ were upregulated and $1533 \mathrm{mRNAs}$ were downregulated compared to controls. A clustering analysis of differentially expressed mRNAs related to osteoblast differentiation is shown in Figure 8. The changes in expression of RUNX2 and CTNNB1 are shown in Figure 9. While the expression of CTNNB1 was increased dose-dependently, the expression of RUNX2 was highest at $6 \mathrm{ng} / \mathrm{mL}$ and the expression decreased at the higher dose of $10 \mathrm{ng} / \mathrm{mL}$ (Figure 9A,B). The phosphoinositide-3-kinase-protein kinase B/Akt (PI3K/AKT) signaling pathway was involved in the target genes chosen for stem cell differentiation (Figure 10).

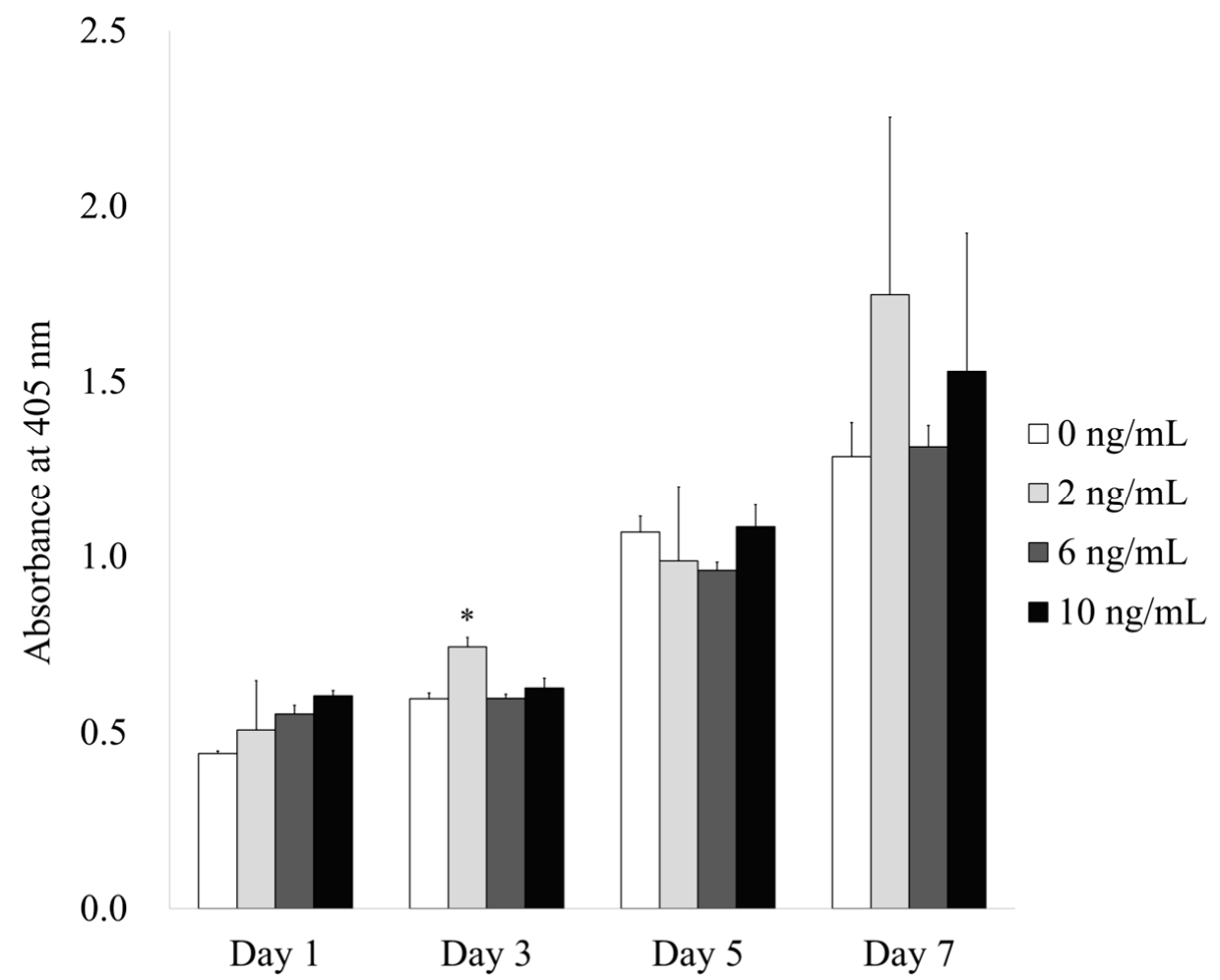

Figure 5. Alkaline phosphatase activity on Days 1, 3, 5, and 7. * Statistically significant differences were noted when compared with the $0 \mathrm{ng} / \mathrm{mL}$ group on Day $3(p<0.05)$. 

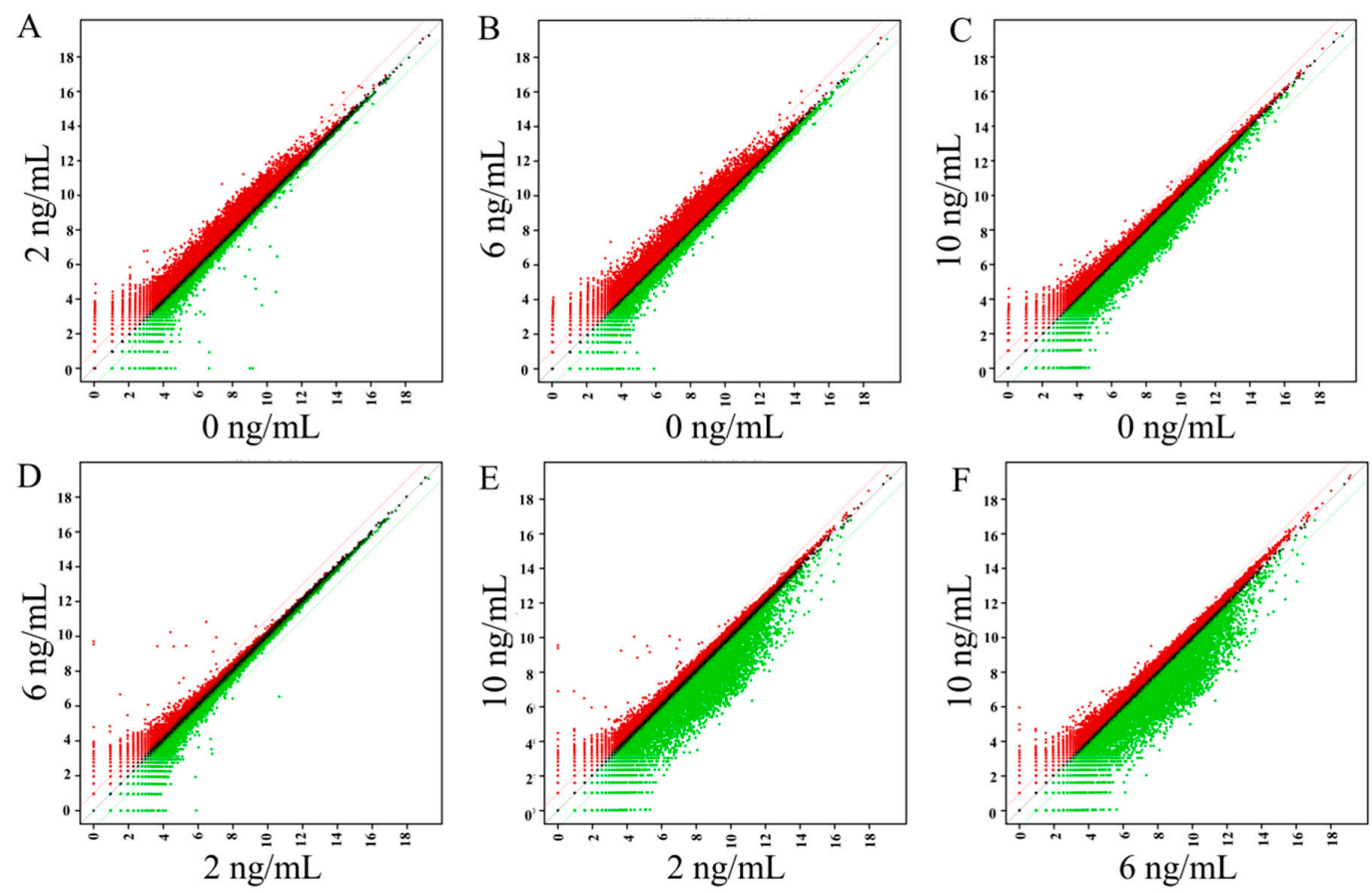

Figure 6. Scatter plots showing the expression of BMP-4 at $0,2,6$, and $10 \mathrm{ng} / \mathrm{mL}$ ( $\mathrm{x}$, y-axis: Relative expression level; red indicates that the expression level of the $y$-value is higher than that of the $\mathrm{x}$-value and green indicates that the expression level of the $\mathrm{y}$-value is lower than that of the $\mathrm{x}$-value). (A) 2/0, (B) 6/0, (C) 10/0, (D) 6/2, (E) 10/2, and (F) 10/6 ng/mL.
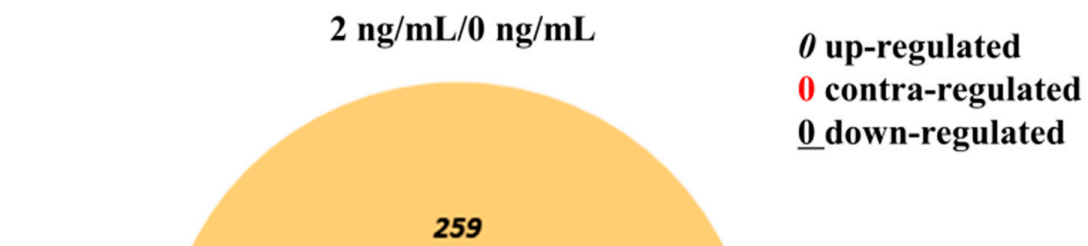

$\underline{296}$

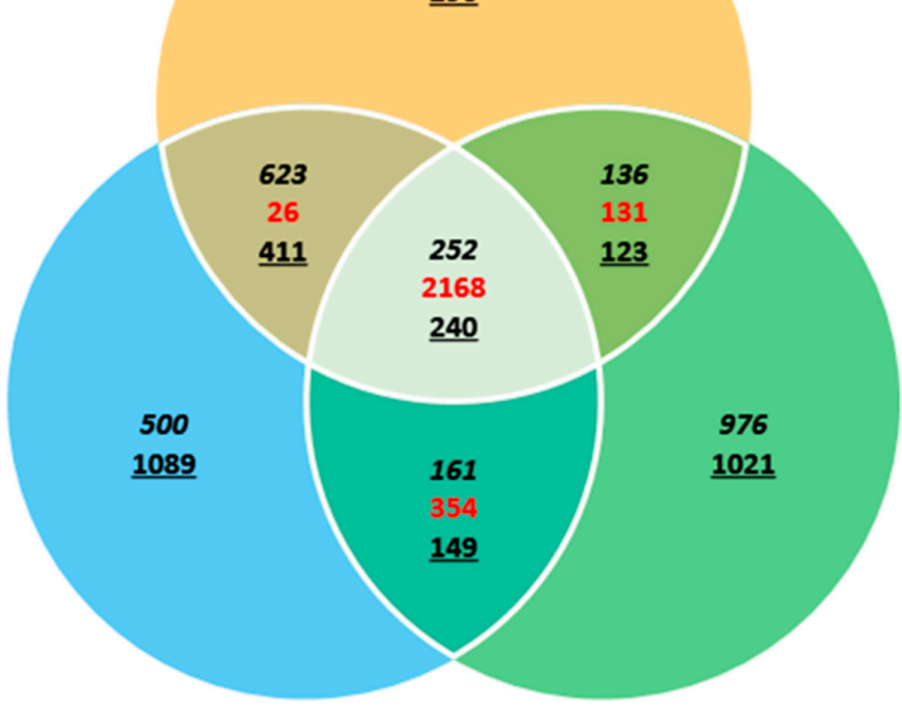

$6 \mathrm{ng} / \mathrm{mL} / 0 \mathrm{ng} / \mathrm{mL}$

$10 \mathrm{ng} / \mathrm{mL} / 0 \mathrm{ng} / \mathrm{mL}$

Figure 7. Venn diagram analysis (fold change, 1.3, log2-normalized read counts of 4 were selected). 


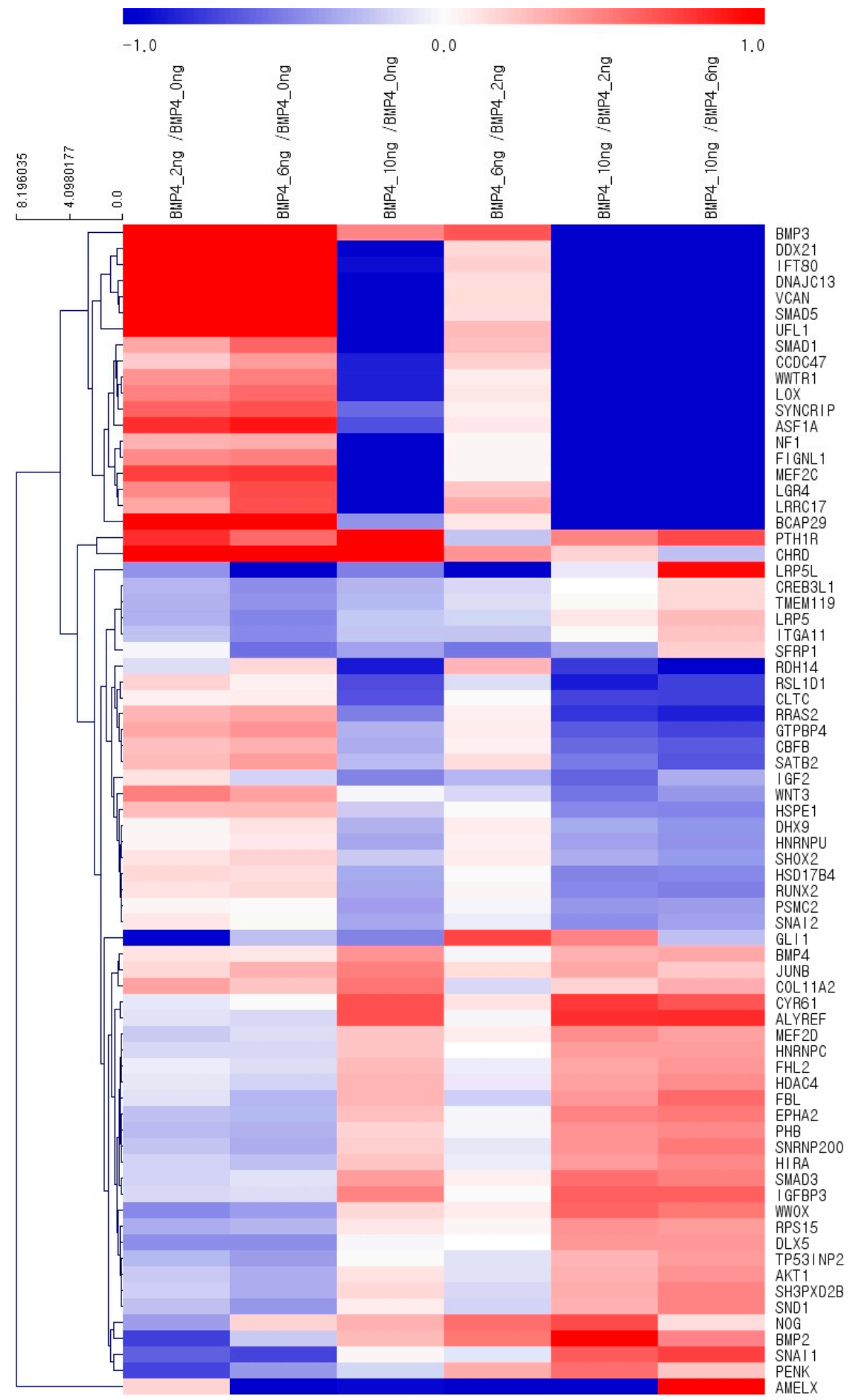

Figure 8. The results of clustering analysis of differentially expressed mRNAs related to osteoblast differentiation (fold change 1.3, $\log 2$-normalized read counts of 4 were selected). 


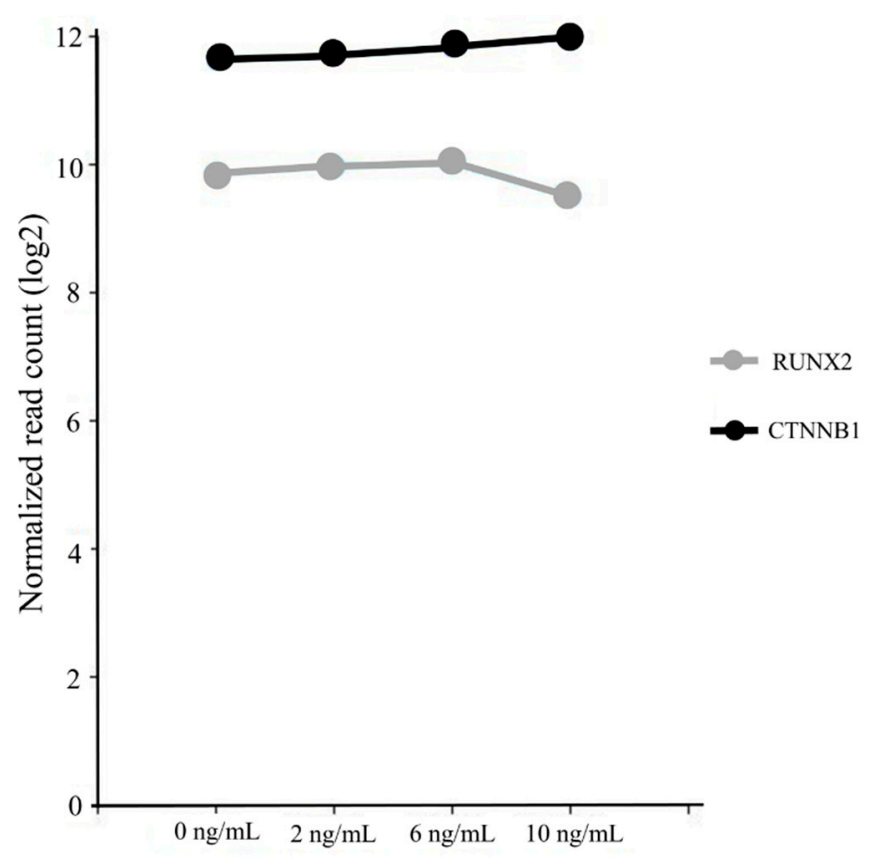

(A)

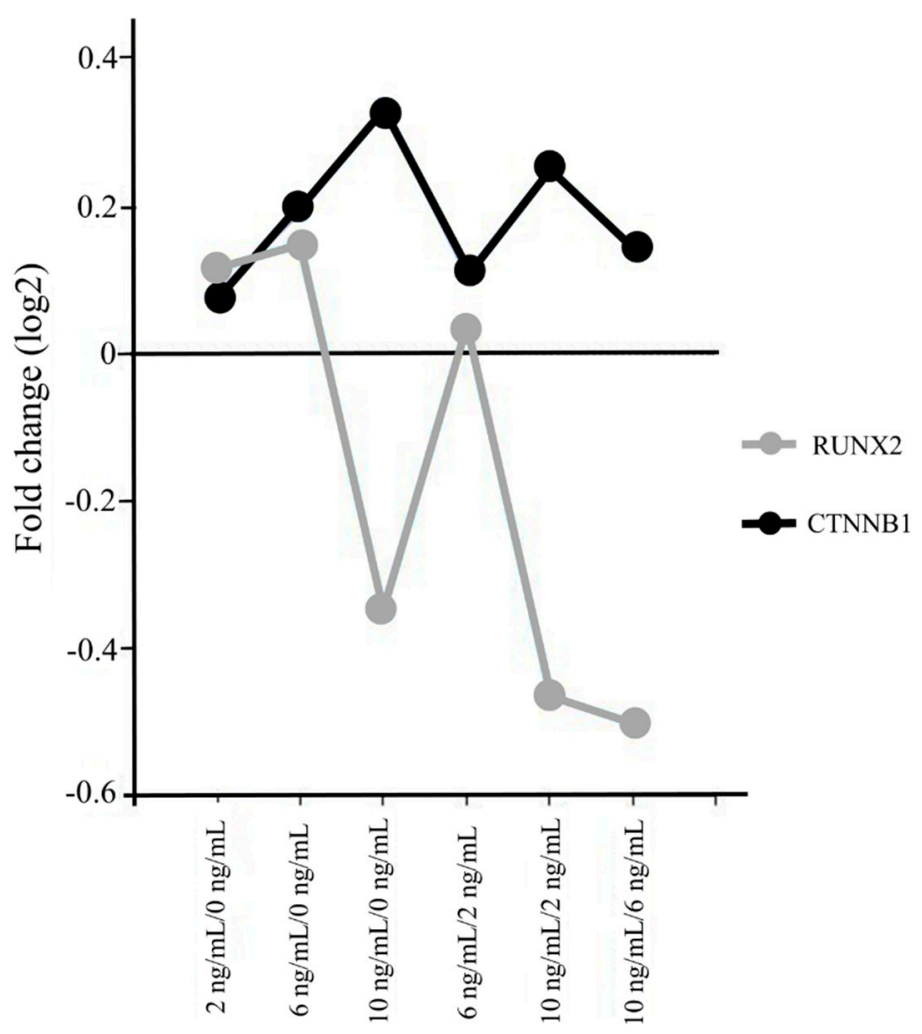

(B)

Figure 9. (A) Log2-normalized read counts regarding the expression of RUNX2 and CTNNB1. (B) Log2 fold change regarding the expression of RUNX2 and CTNNB1. 


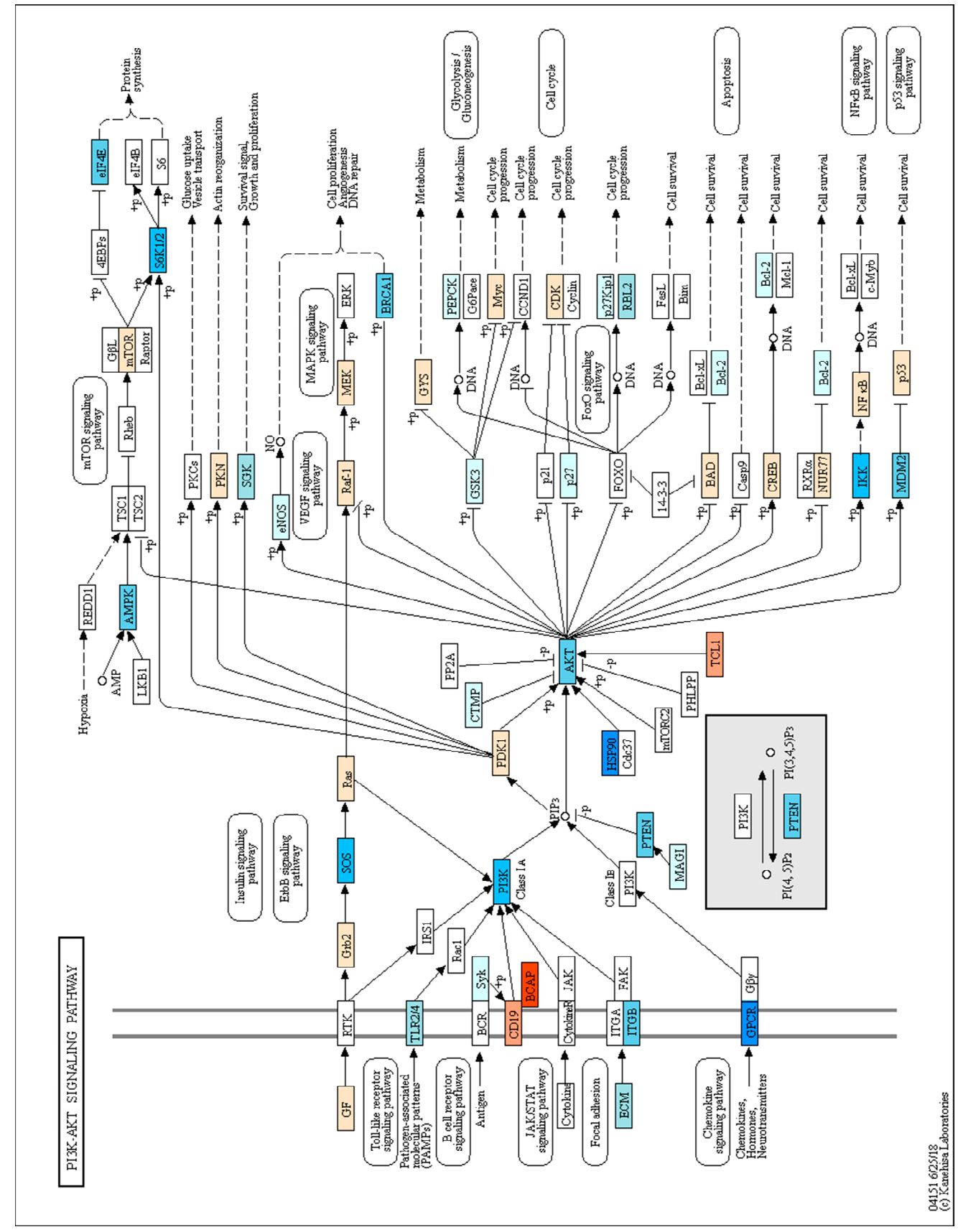

Figure 10. PI3K-AKT signaling pathway.

\section{Discussion}

In this study, we examined the effects of BMP-4 on stem cell spheroids under predetermined concentrations of 2,6 , and $10 \mathrm{ng} / \mathrm{mL}$ and found that the application of BMP-4 increased alkaline phosphatase activity and the expression of RUNX2 and CTNNB1 without affecting cellular viability.

BMP-4 is reported to act as a regulator for osteogenic differentiation and has been shown to induce endochondral and intra-membranous bone formation [12,24]. In a previous report, BMP-4 carried by liposomes seemed to improve the healing process in alveolar bone [25]. Similarly, the expression of BMP-4 appeared to be associated with normal bone homeostasis and the remodeling of grafted and nongrafted maxillary sites [26]. Additionally, BMP-4 induced osteogenic differentiation of mouse skin-derived fibroblasts and dermal papilla cells [24]. Furthermore, a study testing the effects of abnormal BMP-4 expression in the blood of diabetic participants found that low expression of BMP-4 
hindered the osteogenic function of bone marrow-derived stem cells [27]. This study also clearly showed that BMP-4 increased osteogenic differentiation of stem cell spheroids composed of gingiva-derived mesenchymal stem cells.

The effects of BMP-4 concentration were tested in previous reports [24,28-32]. Application of $20 \mathrm{ng} / \mathrm{mL}$ BMP-4 to primary osteoblastic cells derived from the calvaria resulted in an enhancement in fibronectin synthesis [28]. Treatment with $70 \mathrm{ng} / \mathrm{mL}$ of BMP-4 stimulated vascular endothelial growth factor (VEGF) synthesis in osteoblasts [29]. Similarly, the use of $30 \mathrm{ng} / \mathrm{mL}$ BMP-4 was associated with an increase in osteoprotegerin synthesis in osteoblast-like MC3T3-E1 cells [30]. At a concentration of $50 \mathrm{ng} / \mathrm{mL}$, BMP-4 induced osteogenic differentiation of mouse skin-derived fibroblasts and dermal papilla cells [24]. Treatment with $500 \mathrm{ng} / \mathrm{mL}$ BMP-4 resulted in in vitro osteogenic differentiation of C2C12 cells derived from mouse muscle [31]. Primary human mesenchymal stem cells were treated with 100, 200, or $500 \mathrm{ng} / \mathrm{mL}$ BMP-4 and cells were stained with Alizarin red to detect calcium deposition, and the results showed that the $500 \mathrm{ng} / \mathrm{mL}$ dose produced the highest value [32]. Moreover, MG63 and Sao2 osteosarcoma cell lines were treated with $25 \mathrm{ng} / \mathrm{mL}$ BMP-4 to evaluate the cell cycle distributions, and the results showed that BMP-4 seemed to increase the percent of cells in the G0/G1 phases and decrease the percent of cells in the synthetic and/or G2/M phases [33]. This study showed that the application of 2 or $6 \mathrm{ng} / \mathrm{mL}$ BMP-4 could increase the osteogenic differentiation of stem cell spheroids and the expression of related genes. The variety of effects seen across concentrations may be partly due to the differences in cell types, culture conditions, and culture times [34,35].

In a previous report, modification of the roughened anodized titanium implant was done by wet coating with growth factors [36]. In another study, the coating of the titanium implants was obtained by absorption of growth factors after coating the surface with the collagen [17]. The results showed that coating with collagen, chondroitin sulphate, and BMP-4 showed the highest bone-to-implant contact. Enhanced coating can be obtained by applying various methods including chemical bonding, polymer layer, and covering layer [37].

BMP-4 has been proposed to act on various pathways [38-40]. A previous report showed that BMP-4 affected the osteogenic differentiation and mineralization of bone marrow-derived stem cells through Wnt/ $\beta$-catenin activation [38]. This study suggested the involvement of the PI3K/AKT pathway, and a previous report showed that the mineralization of osteoblasts occurred through the PI3K/AKT pathway [40].

Sequencing was performed to measure genome-wide mRNA expression levels and to investigate the possible mechanisms behind the observed effects of BMP-4. RUNX2 and CTNNB1 (which affect $\beta$-catenin expression) are major regulators for osteoblastic lineage [41,42]. RUNX2 is reported to be essential for osteogenic differentiation and is weakly expressed in uncommitted mesenchymal cells but shows up-regulated expression in preosteoblasts [43]. The expression of the osteoblast marker gene RUNX2 was significantly up-regulated in cell spheroids composed of adipose-derived stem cells [44]. $\beta$-catenin is reported to be involved in activation of the osteogenic-related signaling pathway $[45,46]$. $\beta$-catenin is also reported to control the differentiation of bone-forming osteoblasts and bone-resorbing osteoclasts [47]. Furthermore, $\beta$-catenin is involved in mediating the viability of osteoblasts [48]. In this report, expression levels of both CTNNB1 and RUNX2 were up-regulated with the application of BMP-4. The focusing on RUNX2 and CTNNB1 expression with agonists may produce enhanced functionality. BMP-4 can be suggested as a coating material for the stem cell culture for enhancing for osteogenic differentiation [49]. Moreover, spheroids can be made with stem cells mixed with BMP-4 or impregnated with BMP using fibers [50].

\section{Conclusions}

This study evaluated the effects of BMP-4 on cellular viability, osteogenic differentiation, and global mRNA expression using stem cell spheroids composed. Together, these results revealed that the application of BMP-4 increased alkaline phosphatase activity and CTNNB1 and RUNX2 expression without affecting cellular viability. Based on this research, the coating with BMP-4 can be applied 
when stem cells are utilized. BMP-4 can be suggested as a coating material for stem cell cultures. Spheroids impregnated with BMP-4 can be suggested for the bone regeneration field as stem cell therapy.

Author Contributions: Conceptualization, J.-Y.T., Y.-H.P., Y.K. and J.-B.P.; methodology J.-Y.T., Y.-H.P. and J.-B.P.; validation, J.-Y.T., Y.-H.P. and J.-B.P.; formal analysis, J.-Y.T., Y.-H.P. and J.-B.P.; writing-original draft preparation, J.-Y.T., Y.-H.P., Y.K. and J.-B.P.; and writing-review and editing, J.-Y.T., Y.-H.P., Y.K. and J.-B.P. All authors have read and agreed to the published version of the manuscript.

Funding: This study was funded by the National Research Foundation of Korea (NRF) grant funded by the Korea government (MSIT) (No. 2020R1A2C4001624). This research was also funded by Research Fund of Seoul St. Mary's Hospital, The Catholic University of Korea.

Conflicts of Interest: The authors have no competing interests regarding this study.

\section{References}

1. Castro-Manrreza, M.E.; Montesinos, J.J. Immunoregulation by mesenchymal stem cells: Biological aspects and clinical applications. J. Immunol. Res. 2015, 2015, 394917. [CrossRef] [PubMed]

2. Lee, S.-I.; Yeo, S.-I.; Kim, B.-B.; Ko, Y.; Park, J.-B. Formation of size-controllable spheroids using gingiva-derived stem cells and concave microwells: Morphology and viability tests. Biomed. Rep. 2016, 4, 97-101. [CrossRef]

3. Lee, S.-I.; Ko, Y.; Park, J.-B. Evaluation of the shape, viability, stemness and osteogenic differentiation of cell spheroids formed from human gingiva-derived stem cells and osteoprecursor cells. Exp. Ther. Med. 2017, 13, 3467-3473. [CrossRef] [PubMed]

4. Watt, F.M.; Driskell, R.R. The therapeutic potential of stem cells. Philos Trans. R. Soc. Lond. B Biol. Sci. 2010, 365, 155-163. [CrossRef] [PubMed]

5. Montanez-Sauri, S.I.; Beebe, D.J.; Sung, K.E. Microscale screening systems for 3D cellular microenvironments: Platforms, advances, and challenges. Cell Mol. Life Sci. 2015, 72, 237-249. [CrossRef]

6. Langhans, S.A. Three-Dimensional in Vitro Cell Culture Models in Drug Discovery and Drug Repositioning. Front. Pharmacol. 2018, 9, 6.

7. Edmondson, R.; Broglie, J.J.; Adcock, A.F.; Yang, L. Three-dimensional cell culture systems and their applications in drug discovery and cell-based biosensors. Assay Drug Dev. Technol. 2014, 12, 207-218. [CrossRef] [PubMed]

8. Napolitano, A.P.; Dean, D.M.; Man, A.J.; Youssef, J.; Ho, D.N.; Rago, A.P.; Lech, M.P.; Morgan, J.R. Scaffold-free three-dimensional cell culture utilizing micromolded nonadhesive hydrogels. Biotechniques 2007, 43, 494-500. [CrossRef] [PubMed]

9. Petrenko, Y.; Syková, E.; Kubinová, Š. The therapeutic potential of three-dimensional multipotent mesenchymal stromal cell spheroids. Stem Cell Res. Ther. 2017, 8, 94. [CrossRef] [PubMed]

10. He, J.; Han, X.; Wang, S.; Zhang, Y.; Dai, X.; Liu, B.; Liu, L.; Zhao, X. Cell sheets of co-cultured BMP-2-modified bone marrow stromal cells and endothelial progenitor cells accelerate bone regeneration in vitro. Exp. Ther. Med. 2019, 18, 3333-3340. [CrossRef] [PubMed]

11. Bragdon, B.; Moseychuk, O.; Saldanha, S.; King, D.; Julian, J.; Nohe, A. Bone Morphogenetic Proteins: A critical review. Cell Signal 2011, 23, 609-620. [CrossRef] [PubMed]

12. Rahman, M.S.; Akhtar, N.; Jamil, H.M.; Banik, R.S.; Asaduzzaman, S.M. TGF- $\beta$ /BMP signaling and other molecular events: Regulation of osteoblastogenesis and bone formation. Bone Res. 2015, 3, 15005. [CrossRef] [PubMed]

13. Modica, S.; Wolfrum, C. The dual role of BMP4 in adipogenesis and metabolism. Adipocyte 2017, 6, 141-146. [CrossRef] [PubMed]

14. Li, Q.; Wijesekera, O.; Salas, S.J.; Wang, J.Y.; Zhu, M.; Aprhys, C.; Chaichana, K.L.; Chesler, D.A.; Zhang, H.; Smith, C.L.; et al. Mesenchymal stem cells from human fat engineered to secrete BMP4 are nononcogenic, suppress brain cancer, and prolong survival. Clin. Cancer Res. 2014, 20, 2375-2387. [CrossRef]

15. Kang, Q.; Sun, M.H.; Cheng, H.; Peng, Y.; Montag, A.G.; Deyrup, A.T.; Jiang, W.; Luu, H.H.; Luo, J.; Szatkowski, J.P.; et al. Characterization of the distinct orthotopic bone-forming activity of 14 BMPs using recombinant adenovirus-mediated gene delivery. Gene Ther. 2004, 11, 1312-1320. [CrossRef]

16. Gluhak-Heinrich, J.; Guo, D.; Yang, W.; Harris, M.A.; Lichtler, A.; Kream, B.; Zhang, J.; Feng, J.Q.; Smith, L.C.; Dechow, P.; et al. New roles and mechanism of action of BMP4 in postnatal tooth cytodifferentiation. Bone 2010, 46, 1533-1545. [CrossRef] 
17. Stadlinger, B.; Pilling, E.; Mai, R.; Bierbaum, S.; Berhardt, R.; Scharnweber, D.; Eckelt, U. Effect of biological implant surface coatings on bone formation, applying collagen, proteoglycans, glycosaminoglycans and growth factors. J. Mater. Sci. Mater. Med. 2008, 19, 1043-1049. [CrossRef]

18. Son, J.; Tae, J.Y.; Min, S.K.; Ko, Y.; Park, J.B. Fibroblast growth factor-4 maintains cellular viability while enhancing osteogenic differentiation of stem cell spheroids in part by regulating RUNX2 and BGLAP expression. Exp. Ther. Med. 2020, 20, 2013-2020. [CrossRef]

19. Trapnell, C.; Pachter, L.; Salzberg, S.L. TopHat: Discovering splice junctions with RNA-Seq. Bioinformatics 2009, 25, 1105-1111. [CrossRef]

20. Gentleman, R.C.; Carey, V.J.; Bates, D.M.; Bolstad, B.; Dettling, M.; Dudoit, S.; Ellis, B.; Gautier, L.; Ge, Y.; Gentry, J.; et al. Bioconductor: Open software development for computational biology and bioinformatics. Genome Biol. 2004, 5, 80. [CrossRef]

21. Huang, D.W.; Sherman, B.T.; Tan, Q.; Collins, J.R.; Alvord, W.G.; Roayaei, J.; Stephens, R.; Baseler, M.W.; Lane, H.C.; Lempicki, R.A. The DAVID Gene Functional Classification Tool: A novel biological module-centric algorithm to functionally analyze large gene lists. Genome Biol. 2007, 8, 183. [CrossRef] [PubMed]

22. Kanehisa, M.; Furumichi, M.; Tanabe, M.; Sato, Y.; Morishima, K. KEGG: New perspectives on genomes, pathways, diseases and drugs. Nucleic Acids Res. 2017, 45, 353-361. [CrossRef] [PubMed]

23. Lee, H.; Min, S.K.; Song, Y.; Park, Y.H.; Park, J.B. Bone morphogenetic protein-7 upregulates genes associated with osteoblast differentiation, including collagen I, Sp7 and IBSP in gingiva-derived stem cells. Exp. Ther. Med. 2019, 18, 2867-2876. [CrossRef] [PubMed]

24. Myllylä, R.M.; Haapasaari, K.M.; Lehenkari, P.; Tuukkanen, J. Bone morphogenetic proteins 4 and 2/7 induce osteogenic differentiation of mouse skin derived fibroblast and dermal papilla cells. Cell Tissue Res. 2014, 355, 463-470. [CrossRef]

25. Ferreira, C.L.; Abreu, F.A.; Silva, G.A.; Silveira, F.F.; Barreto, L.B.; Paulino Tde, P.; Miziara, M.N.; Alves, J.B. TGF- $\beta 1$ and BMP-4 carried by liposomes enhance the healing process in alveolar bone. Arch. Oral Biol. 2013, 58, 646-656. [CrossRef] [PubMed]

26. Torrecillas-Martínez, L.; Galindo-Moreno, P.; Ávila-Ortiz, G.; Ortega-Oller, I.; Monje, A.; Hernández-Cortés, P.; Aguilar, D.; O'Valle, F. Significance of the immunohistochemical expression of bone morphogenetic protein-4 in bone maturation after maxillary sinus grafting in humans. Clin. Implant Dent. Relat. Res. 2016, 18, 717-724. [CrossRef]

27. Liang, C.; Sun, R.; Xu, Y.; Geng, W.; Li, J. Effect of the abnormal expression of BMP-4 in the blood of diabetic patients on the osteogenic differentiation potential of alveolar BMSCs and the rescue effect of metformin: A bioinformatics-based study. Biomed. Res. Int. 2020, 2020, 7626215. [CrossRef]

28. Tang, C.H.; Yang, R.S.; Liou, H.C.; Fu, W.M. Enhancement of fibronectin synthesis and fibrillogenesis by BMP-4 in cultured rat osteoblast. J. Bone Miner Res. 2003, 18, 502-511. [CrossRef]

29. Kondo, A.; Otsuka, T.; Kuroyanagi, G.; Yamamoto, N.; Matsushima-Nishiwaki, R.; Mizutani, J.; Kozawa, O.; Tokuda, H. Resveratrol inhibits BMP-4-stimulated VEGF synthesis in osteoblasts: Suppression of S6 kinase. Int. J. Mol. Med. 2014, 33, 1013-1018. [CrossRef]

30. Fujita, K.; Otsuka, T.; Yamamoto, N.; Kainuma, S.; Ohguchi, R.; Kawabata, T.; Sakai, G.; Kuroyanagi, G.; Matsushima-Nishiwaki, R.; Kozawa, O.; et al. (-)-Epigallocatechin gallate but not chlorogenic acid upregulates osteoprotegerin synthesis through regulation of bone morphogenetic protein-4 in osteoblasts. Exp. Ther. Med. 2017, 14, 417-423. [CrossRef]

31. Lee, S.H.; Hwang, J.W.; Han, Y.; Lee, K.Y. Synergistic stimulating effect of 2-hydroxymelatonin and BMP-4 on osteogenic differentiation in vitro. Biochem. Biophys. Res. Commun. 2020, 527, 941-946. [CrossRef] [PubMed]

32. Lavery, K.; Swain, P.; Falb, D.; Alaoui-Ismaili, M.H. BMP-2/4 and BMP-6/7 differentially utilize cell surface receptors to induce osteoblastic differentiation of human bone marrow-derived mesenchymal stem cells. J. Biol. Chem. 2008, 283, 20948-20958. [CrossRef]

33. Chang, S.F.; Chang, T.K.; Peng, H.H.; Yeh, Y.T.; Lee, D.Y.; Yeh, C.R.; Zhou, J.; Cheng, C.K.; Chang, C.A.; Chiu, J.J. BMP-4 induction of arrest and differentiation of osteoblast-like cells via p21 CIP1 and p27 KIP1 regulation. Mol. Endocrinol. 2009, 23, 1827-1838. [CrossRef] [PubMed]

34. van der Sanden, B.; Dhobb, M.; Berger, F.; Wion, D. Optimizing stem cell culture. J. Cell Biochem. 2010, 111, 801-807. [CrossRef] 
35. Kang, S.H.; Park, J.B.; Kim, I.; Lee, W.; Kim, H. Assessment of stem cell viability in the initial healing period in rabbits with a cranial bone defect according to the type and form of scaffold. J. Periodontal Implant Sci. 2019, 49, 258-267. [CrossRef]

36. Bates, C.; Marino, V.; Fazzalari, N.L.; Bartold, P.M. Soft tissue attachment to titanium implants coated with growth factors. Clin. Implant Dent. Relat. Res. 2013, 15, 53-63. [CrossRef]

37. Wang, J.; Guo, J.; Liu, J.; Wei, L.; Wu, G. BMP-functionalised coatings to promote osteogenesis for orthopaedic implants. Int. J. Mol. Sci. 2014, 15, 10150-10168. [CrossRef]

38. Ruan, Y.; Kato, H.; Taguchi, Y.; Yamauchi, N.; Umeda, M. Irradiation by high-intensity red light-emitting diode enhances human bone marrow mesenchymal stem cells osteogenic differentiation and mineralization through Wnt/ $\beta$-catenin signaling pathway. Lasers Med. Sci. 2020, 25, 1-11. [CrossRef]

39. Wang, Y.; He, H.; Cao, Z.; Fang, Y.; Du, M.; Liu, Z. Regulatory effects of bone morphogenetic protein-4 on tumour necrosis factor- $\alpha$-suppressed Runx 2 and osteoprotegerin expression in cementoblasts. Cell Prolif. 2017, 50, e12344. [CrossRef]

40. Ayala-Peña, V.B.; Scolaro, L.A.; Santillán, G.E. ATP and UTP stimulate bone morphogenetic protein-2,-4 and -5 gene expression and mineralization by rat primary osteoblasts involving PI3K/AKT pathway. Exp. Cell Res. 2013, 319, 2028-2036. [CrossRef] [PubMed]

41. Vega, O.A.; Lucero, C.M.J.; Araya, H.F.; Jerez, S.; Tapia, J.C.; Antonelli, M.; Salazar-Onfray, F.; Las Heras, F.; Thaler, R.; Riester, S.M.; et al. Wnt/ $\beta$-Catenin Signaling Activates Expression of the Bone-Related Transcription Factor RUNX2 in Select Human Osteosarcoma Cell Types. J. Cell Biochem. 2017, 118, 3662-3674. [CrossRef] [PubMed]

42. Tae, J.Y.; Lee, H.; Lee, H.; Ko, Y.; Park, J.B. Osteogenic potential of cell spheroids composed of varying ratios of gingiva-derived and bone marrow stem cells using concave microwells. Exp. Ther. Med. 2018, 16, 2287-2294. [CrossRef] [PubMed]

43. Hopkins, A.; Mirzayans, F.; Berry, F. Foxc1 Expression in Early Osteogenic Differentiation Is Regulated by BMP4-SMAD Activity. J. Cell Biochem. 2016, 117, 1707-1717. [CrossRef] [PubMed]

44. Rumiński, S.; Kalaszczyńska, I.; Długosz, A.; Lewandowska-Szumieł, M. Osteogenic differentiation of human adipose-derived stem cells in 3D conditions-Comparison of spheroids and polystyrene scaffolds. Eur. Cell Mater. 2019, 37, 382-401. [CrossRef]

45. Zhang, J.; He, X.; Chen, X.; Wu, Y.; Dong, L.; Cheng, K.; Lin, J.; Wang, H.; Weng, W. Enhancing osteogenic differentiation of BMSCs on high magnetoelectric response films. Mater. Sci. Eng. C Mater. Biol. Appl. 2020, 113, 110970. [CrossRef]

46. Kim, B.B.; Kim, M.; Park, Y.H.; Ko, Y.; Park, J.B. Short-term application of dexamethasone on stem cells derived from human gingiva reduces the expression of RUNX2 and $\beta$-catenin. J. Int. Med. Res. 2017, 45, 993-1006. [CrossRef]

47. Kramer, I.; Halleux, C.; Keller, H.; Pegurri, M.; Gooi, J.H.; Weber, P.B.; Feng, J.Q.; Bonewald, L.F.; Kneissel, M. Osteocyte Wnt/beta-catenin signaling is required for normal bone homeostasis. Mol. Cell Biol. 2010, 30, 3071-3085. [CrossRef]

48. Chu, Y.; Gao, Y.; Yang, Y.; Liu, Y.; Guo, N.; Wang, L.; Huang, W.; Wu, L.; Sun, D.; Gu, W. $\beta$-catenin mediates fluoride-induced aberrant osteoblasts activity and osteogenesis. Environ. Pollut. 2020, 265, 114734. [CrossRef]

49. Liu, D.; Pavathuparambil Abdul Manaph, N.; Al-Hawwas, M.; Bobrovskaya, L.; Xiong, L.L.; Zhou, X.F. Coating Materials for Neural Stem/Progenitor Cell Culture and Differentiation. Stem Cells Dev. 2020, 29, 463-474. [CrossRef]

50. Ahmad, T.; Byun, H.; Lee, J.; Madhurakat Perikamana, S.K.; Shin, Y.M.; Kim, E.M.; Shin, H. Stem cell spheroids incorporating fibers coated with adenosine and polydopamine as a modular building blocks for bone tissue engineering. Biomaterials 2020, 230, 119652. [CrossRef]

Publisher's Note: MDPI stays neutral with regard to jurisdictional claims in published maps and institutional affiliations. 